\title{
Mexican investment after the Tequila crisis: basic economics, "confidence" effects or market imperfections?
}

\author{
Daniel Lederman ${ }^{\text {a,* }}$, Ana María Menéndez ${ }^{\text {a }}$ Guillermo Perry a , \\ Joseph Stiglitz ${ }^{\mathrm{b}}$
}

${ }^{a}$ Chief Economist Office, Latin America and the Caribbean Region, The World Bank, $1818 \mathrm{H}$ Street N.W., Washington DC 20433, USA

b Department of Economics, Columbia University, New York, NY, USA

\begin{abstract}
This study provides an empirical investigation of the determinants of the growth of investment in Mexico, especially after the Tequila crisis. The paper uses the Generalized Method of Moments estimator to determine if investment can be explained with a standard investment function. The model predicts well the recovery of investment; the tradable sector has an accelerator effect that exceeds that of the non-tradable sector. Domestic real interest rates and real exchange rate volatility are also significant. Results support the hypothesis of a "confidence" effect during the 1982-1983 crisis, but not during the Tequila crisis. There is also evidence of credit rationing.
\end{abstract}

(C) 2003 Elsevier Science Ltd. All rights reserved.

JEL classification: E22; F40

Keywords: Investment; Mexico crisis; Confidence effect; Tradable non-tradable sector

\section{Introduction}

The Mexican economy experienced a sharp contraction in 1995, after the Peso devaluation of December 22, 1994. Output growth was $-6.2 \%$ in 1995, and became positive during the first three quarters of 1996. In 1996 and 1997 the Mexican econ-

\footnotetext{
* Corresponding author. Tel.: +1-202-473-9015; fax: +1-202-522-7528.
}

E-mail address: dlederman@worldbank.org (D. Lederman). 
omy grew at healthy rates of $5.1 \%$ and $6.8 \%$, respectively. It has been suggested by some authors that the decisive response of fiscal and monetary authorities supported by a generous financial package of billions of dollars announced in March 9, 1995, were crucial for the rapid recovery of lost investor confidence. These observers further argue that these policies prompted a rapid stabilization of the currency and a turnaround in investment and economic activity. ${ }^{1}$

The aim of the present paper is to study the behavior of Mexican investment with a standard model. Extensions of the model test whether there were "confidence" effects during times of crisis and evaluate the relevance of market imperfections such as market segmentation and credit rationing. Section 2 begins by establishing the stylized facts regarding the contribution of fixed investment to GDP growth since 1993. A simple decomposition analysis shows that until 1997, economic growth after the Tequila crisis recovered primarily due to the behavior of fixed investment. Investment growth declined drastically during 1995, but subsequently rose to levels exceeding pre-crisis levels. Hence the remaining analyses focus on the determinants of the growth rate of fixed investment.

Section 3 presents a theoretical model of investment behavior by a representative firm, which shows that the magnitude of the income accelerator effect depends on the capital intensity of the firm's output. Section 4 focuses on plausible determinants of investment growth in Mexico, based on a standard empirical model of investment behavior. The only addition to standard models is that aggregate investment depends differently on the output of tradable and non-tradable goods.

Section 5 describes the data. Section 6 reviews the estimation strategy, which relies on the General Method of Moments (GMM) estimator to control for the endogeneity of explanatory variables. The estimation strategy includes three specification tests: A Wald test is used to assess whether the sectoral multipliers are statistically different; Hansen's $J$-statistic is used to determine the validity of the set of instrumental variables used in the GMM regressions; and the $Q$-statistic is used to determine if the model specifications suffer from error serial correlation. In addition, this section presents results of seasonal unit root tests for all variables in levels, following the methodology proposed by Hylleberg et al. (1990). Most of the variables in levels have some form of seasonal roots. The exceptions are real interest rates and the volatility of the real exchange rate (RER). These results influenced the estimation strategy by statistically justifying the use of the year-on-year differences of the variables with unit roots. ${ }^{2}$

The GMM regression results are presented in Section 7. The dependent variable is the growth of the share of fixed investment in GDP. The explanatory variables include the growth of the sectoral GDPs, the domestic real interest rate, changes in real-exchange rate (RER) volatility, variations in the relative price of capital, and the lagged dependent variable. This function is estimated for the whole sample (1981:

\footnotetext{
${ }^{1}$ For example, the IMF (1996) p. 25, wrote that "In Mexico, tight fiscal and monetary policies helped reduce actual and expected inflation in the first half of [1995], contributing to further gains in confidence, declines in interest rates, and the stabilization of the peso".

2 Appendix A explains the unit root tests proposed by Hylleberg et al. (1990).
} 
Q1-2000: Q2). The basic model is then extended to test the stability of the coefficient on the domestic real interest rate during periods of crisis. Then we add credit availability (the growth rate of credit to the private sector issued by commercial banks and non-financial institutions) and the US real interest rate to assess whether Mexico has suffered from credit rationing and/or market segmentation. The model was also estimated with a restricted sample (1981-1994), which was then used for an out-ofsample forecast to test the model's ability to predict investment during and after the so-called Tequila crisis.

The results indicate that the tradable sector has a higher multiplier effect on Mexican investment than the non-tradable sector. This result is present in all specifications with the full sample, but not with the restricted sample. Hence this phenomenon emerged after 1994. Two additional determinants of investment are the domestic real interest rate and exchange rate volatility. The impact of domestic interest rates changes during the periods of crises. During the 1982-1983 crisis there was a "confidence" effect, in the sense that the coefficient of the domestic real interest rate was positive. In contrast, during the 1995 crisis this variable had a stronger negative impact on investment than during the rest of the period. After controlling for interest rates, credit availability is important. This evidence is consistent with the credit rationing hypothesis. The US real interest rate is not significant, but has a negative coefficient after controlling for the domestic real interest rate and credit availability. Hence there is only very weak evidence of market segmentation.

Based on calculations of the magnitude of the effects of explanatory variables on the growth of the investment to GDP ratio in 1995 and afterwards, the story that emerges is that Mexican fixed investment growth declined during 1995 due to the devaluation's impact on exchange-rate volatility and the negative income effect that affected output in the short run. The eventual recovery was driven mostly by the high multiplier effect from the tradable sector and the reduction in RER volatility.

\section{Growth decomposition: the stylized facts}

The decomposition of the GDP growth rate into the contributions of its aggregate demand components comes from a transformation of the basic macroeconomic identity $Y=C+I+X-M$, where $Y$ is the level of output, $C$ is the sum of private and public consumption, $I$ is the level of investment, $X$ stands for exports, and $M$ for imports. By first differencing each element, dividing by the ex-ante level of $Y$, and some simple manipulations, the growth of output can be decomposed into the contributions of the growth rates of each of its components:

$$
\begin{gathered}
\Delta Y / Y_{t-1}=\left(C_{t-1} / Y_{t-1}\right) \cdot \Delta C / C_{t-1}+\left(I_{t-1} / Y_{t-1}\right) \cdot \Delta I / I_{t-1} \\
\quad+\left(X_{t-1} / Y_{t-1}\right) \cdot \Delta X / X_{t-1}-\left(M_{t-1} / Y_{t-1}\right) \cdot \Delta M / M_{t-1} .
\end{gathered}
$$

This expression can be easily expanded to include the contribution of more disaggregated demand components. For example, the contribution of gross investment can be further decomposed into the sum of the contribution of fixed investment and 
inventory accumulation. Figure 1 shows the growth rates of GDP and total fixed investment, as well as the latter's contribution to GDP growth, on the basis of yearon-year (i.e., seasonally-adjusted and annualized) growth rates. The graph shows that fixed investment played a key role during and after the Tequila crisis. Fixed capital accumulation declined more than any other demand component during 1995, but also recovered briskly afterwards. ${ }^{3}$ Moreover, the rate of growth of investment during 1996-1997 was significantly higher than during 1993-1994. Although these stylized facts are illustrative, the growth decomposition exercise suffers from the endogeneity of the demand components. The next section introduces the basic economic model that guides the subsequent empirical model.

\section{Theoretical model}

The purpose of the model is to show how the magnitude of the income accelerator depends on the capital intensity of production. The change in the market value of a representative firm can be expressed as a function of current profits and capital gains, minus the value of current investment, plus the discounted value of future profits

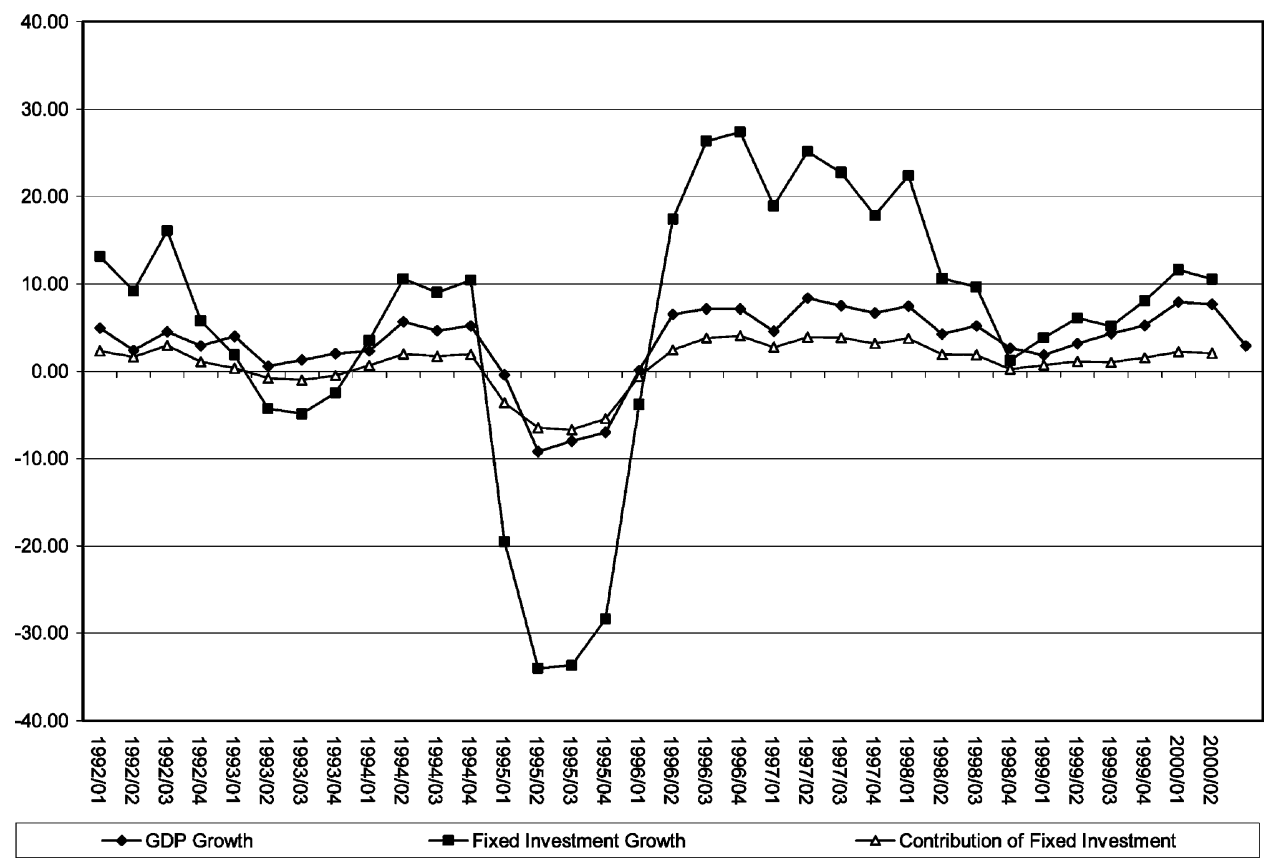

Fig. 1. Mexico: contribution of total fixed investment to GDP growth.

${ }^{3}$ A companion paper (Lederman et al., 2000) compares the contribution of fixed investment with those of other demand components. 
and capital gains. This can be expressed in terms of a simplified version of Rama's (1993) general two-period model as follows:

$$
\begin{aligned}
\Delta V & =\bar{Z}-P_{t}^{K} \cdot\left(\frac{I_{t}}{K_{t}}+\alpha\left(\frac{I_{t}}{K_{t}}\right)^{2}\right)+\frac{1}{\left(1+i_{t}\right)} \cdot\left(p_{t+1} \cdot Q_{t+1}-w_{t+1} \cdot L_{t+1}\right)+\left(\frac{P_{t+1}^{K} \cdot K_{t+1}}{1+i_{t}}\right. \\
& \left.-P_{t}^{K} \cdot K_{t}\right) .
\end{aligned}
$$

The first term, $\bar{Z}$, in eq. (2) represents the sum of current profits and capital gains (losses). It is given at time $t$, and therefore it is a constant. The second term in the right-hand side is the value of current investments, measured as a function of the current nominal price of capital, $P_{t}^{K}$, and it is a convex function of the investment rate (i.e., gross investment over capital stock). The $\alpha$ parameter depends on investment costs, which we will assume to be zero. The third term represents the discounted value of future profits (i.e., revenues minus costs), where $p_{t+1}$ is the nominal price of a unit $Q_{t+1}$ of the firm's output, and $w_{t+1}$ is the labor unit cost. The final term in (2) reflects the discounted value of capital gains (losses) in the second period.

The firm faces three constraints. First, by definition, the future capital stock is:

$$
K_{t+1}=\frac{K_{t}+I_{t}}{1+\delta}=K_{t}\left(\frac{1+\frac{I_{t}}{K_{t}}}{1+\delta}\right) \text { and } \therefore K_{t}=K_{t+1}\left(\frac{1+\delta}{1+\frac{I_{t}}{K_{t}}}\right)
$$

where $\delta$ is the capital stock depreciation rate. Equation (3) says that the capital stock in the second period will be equal to the current capital stock plus current investment, adjusted for the depreciation rate of plant and equipment. Second, the firm faces a technologically determined production function:

$$
Q_{t+1}=K_{t+1}^{1 / \beta} L_{t+1}^{1 / \gamma}
$$

In this specification, production is modeled as a Cobb-Douglas function, where the $\beta$ and $\gamma$ are the units of capital and labor needed to produce one unit of output. Solving for $L_{t+1}$,

$$
L_{t+1}=Q_{t+1}^{\gamma} K_{t+1}^{-\theta},
$$

where $\theta=(\gamma / \beta)$ is the labor intensity of output (i.e., units of labor required to produce one unit of output divided by units of capital required to produce one unit of output). $\theta, \beta$ and $\gamma$ are unconstrained positive numbers. Third, the firm faces an aggregate demand function:

$$
Q_{t+1}=\left(\frac{Y_{t+1}}{F}\right) \cdot\left(\frac{p_{t+1}}{P_{t+1}}\right)^{-\sigma},
$$

where $Y_{t+1}$ is total aggregate demand, and $F$ is the total number of firms in this economy. $p_{t+1} / P_{t+1}$ is the relative price of the firm's output measured with respect 
to the consumer price index. The $\sigma$ parameter is the relative price elasticity of demand for the firm's output, and it will depend on the economy's market structure. Under perfect competition $\sigma \Rightarrow \infty$; under monopolistic competition $\sigma>1$; and in an "effective demand" model $\sigma=0$. The latter case can emerge in the context of binding contracts negotiated in the past, for example. Since our purpose here is to highlight the importance of factor intensities, the effective demand model will be used for the rest of the analysis (see Rama, 1993 for comparisons of the various models).

By inserting (3) into the last term in (2), and after some manipulations, the objective function of the firm becomes

$$
\Delta V=\bar{Z}+\frac{1}{1+i_{t}} \cdot\left(p_{t+1} Q_{t+1}-w_{t+1} L_{t+1}-c_{t+1} K_{t+1}\right),
$$

where $c_{t+1} \approx p_{t}^{K}\left\{\delta+i_{t}-\left[\left(p_{t+1}^{K} / p_{t}^{K}\right)-1\right]\right\}$, assuming that $\delta \cdot i_{t}=0 . c_{t+1}$ is the user cost of capital, or the flow price of capital services. It is the nominal price of capital goods times the depreciation charge per unit of capital $(\delta)$ plus the nominal interest rate deflated by the inflation of capital goods $\left\{i_{t}-\left[\left(p_{t+1}^{K} / p_{t}^{K}\right)-1\right]\right\}$. And by inserting (5) and (6) - with the assumption that $\sigma=0$-into (7), the objective function of the firm becomes

$$
\Delta V=\bar{Z}+\frac{1}{1+i_{t}} \cdot\left(p_{t+1} \frac{Y_{t+1}}{F}-w_{t+1}\left(\frac{Y_{t+1}}{F}\right)^{\theta \beta} K_{t+1}^{-\theta}-c_{t+1} K_{t+1}\right) .
$$

The firm maximizes $\Delta V$ with respect to its future capital stock $K_{t+1}$. The firstorder condition for this maximization problem is:

$$
K_{t+1}^{-(\theta+1)}=\frac{1}{\theta} \cdot \frac{c_{t+1}}{w_{t+1}} \cdot\left(\frac{Y_{t+1}}{F}\right)^{-\theta \beta} .
$$

After taking the natural logarithms of both sides, recognizing that $\hat{K}_{t+1} \approx\left(I_{t} / K_{t}\right)-$ $\delta$, and expressing (9) in growth rates, then the optimal investment rule is: ${ }^{4}$

$$
\frac{I_{t}}{K_{t}}=\delta-\frac{1}{\theta+1} \cdot\left(\frac{\hat{c}_{t+1}}{w_{t+1}}\right)+\frac{\theta \beta}{\theta+1} \cdot\left(\frac{\hat{Y}_{t+1}}{F}\right) .
$$

At this point, note that the investment rate depends on a constant $(\delta)$, falls with increases in the growth rate of the user cost of capital and rises with the growth of aggregate demand. To examine the role of the capital intensity of output, it is helpful to recall that $\beta=(\gamma / \theta)$, and (10) can be rewritten as:

$$
\frac{I_{t}}{K_{t}}=\delta-\frac{1}{\theta+1} \cdot\left(\frac{\hat{c}_{t+1}}{w_{t+1}}\right)+\frac{\gamma}{\theta+1} \cdot\left(\frac{\hat{Y}_{t+1}}{F}\right) .
$$

In (11) we see that the optimal investment rate will depend on the level of aggregate demand, as reflected in the last term on the right-hand side. The magnitude of this effect is determined by $\gamma /(\theta+1)$. This expression says that as the units of capital

\footnotetext{
4 The "-" denotes growth rates. Note that $\theta$ is assumed constant over time.
} 
required to produce one unit of output rises relative to required units of labor, the demand accelerator is greater. In other words, higher capital intensity of production is associated with higher demand accelerators.

The basic empirical model estimated in this paper controls for variables that determine the user cost of capital, namely the relative price of capital goods and real interest rates. It also includes the output of two sectors (tradables and non-tradables). However, since the capital stock is unobserved, the proxy dependent variable in the model will be the ratio of fixed investment over GDP.

\section{An empirical Mexican investment function}

The growth decomposition exercise indicated that fixed capital formation was crucial for the economic recovery in Mexico after 1995. Also, there is evidence that Mexican investment is linked to the tradable sector (Krueger and Tornell, 1999). We can model Mexican investment as a function of the output of tradables and nontradables, where we expect to find different sector multiplier effects: ${ }^{5}$

$$
\frac{I}{G D P}=\bar{I}+m_{T} \hat{Y}_{T}+m_{N T} \hat{Y}_{N T}+I\left(R I R, p_{K}, \sigma_{R E R}\right)
$$

where $I / G D P$ is the (log of the) level of (private fixed) investment to GDP ratio at constant prices; $\bar{I}$ is a constant, minimum level; and the $m s$ are the corresponding sector multipliers. The "hats" over the sectoral outputs represent growth rates of these variables, as suggested by eq. (11). The last term on the right-hand side is the portion of the investment function that is determined by cost factors, including the real interest rate $(R I R)$, the relative price of capital goods $\left(p_{K}\right)$, and an uncertainty variable, which we identify with the volatility of the real exchange rate $\left(\sigma_{R E R}\right)$. This simple model is broadly consistent with standard empirical models of investment behavior in developing countries (see Rama, 1993), except for the assumption regarding the different sectors' multipliers.

Servén (1998) finds significant negative effects of real exchange-rate uncertainty on investment-output ratios in a cross-country panel framework. Volatility could be an important explanation of the fall of investment during 1995 and during the debt crisis of 1982-1983 in Mexico. It is necessary to consider this effect in order to isolate the direct effect of changes in the relative price of capital goods on fixed capital formation. ${ }^{6}$ The consideration of RER uncertainty is consistent with two plausible assumptions. First, domestic investors can be risk-averse, thus uncertainty may adversely affect private investment. Second, portions of private investments are

\footnotetext{
${ }^{5}$ We expect sector multipliers to be different because of differences in capital intensities between the sectors. This hypothesis remains untested.

${ }^{6}$ Since a large share of capital goods in Mexico are imported (37 percent between 1993-1998), there is a high correlation between the relative price of capital and the RER. Servén (1999) shows that the average share of imported capital goods for developing countries in 1990 was 31.1 percent and 29.3 percent for industrial countries.
} 
irreversible and contribute to sunk costs. Under these circumstances, macroeconomic uncertainty can be associated with swings in the value of private firms, thus hampering productive investment by firms (Pindyck, 1988). Moreover, RER uncertainty could also have an indirect effect on investment through its effect on the output of tradables. As argued by Maloney and Azevedo (1995), uncertainty about expected returns of producing for domestic versus export markets can affect the composition of output. The inclusion of RER uncertainty in the model then helps to isolate the sectoral multiplier effect.

One complication of eq. (12) is that the growth rates of $Y_{T}$ and $Y_{N T}$ are also determined by the investment rate. This problem is addressed by the GMM estimation and the selection of instrumental variables. Another complication is that the empirical specification of (12) might not be adequate if the levels of $I / G D P$ and $Y$ s have the same order of integration. These issues are discussed in Section 6, after the presentation of the data.

\section{The data}

The empirical analyses rely on data from the Mexican statistical agency (INEGI) and the International Monetary Fund. A description of the variables and their sources is presented in Table 1. All data have a quarterly frequency and cover the period between 1981 and the second quarter of 2000.

The dependent variable. The regression model to be estimated is given by eq. (12) with one modification. The theoretical model does not call for this variable to be expressed in its rate of growth. But Section 6 finds that it has a seasonal unit root and therefore it is important to difference it in order to avoid spurious regressions. Hence, the variable to be explained is the growth rate of the investment to GDP ratio at constant prices in local currency.

The explanatory variables. The growth of tradable and non-tradable output, as well as the relative price of capital, are explanatory variables. As a proxy for the output of tradables we use INEGI's GDP series for manufactures and agriculture. For non-tradables, we use construction, energy and water services. All series were expressed at constant prices in local currency units. Regarding the relative price of capital, we use the ratio of the price index of capital goods (which is one of the components used by Mexican authorities to calculate their producer's price index) relative to the consumer price index.

The empirical investment function includes a measure of volatility of the real exchange rate on the right-hand side, as proposed by Servén (1998). This variable is the conditional variance of the innovation of the RER based on the generalized autoregressive conditional heteroskedasticity (GARCH $(1,1)$ ) of the following form:

$$
\begin{aligned}
& R E R_{t}=\alpha_{0}+\beta_{1} R E R_{t-1}+\varepsilon_{t}, \\
& \sigma_{t}^{2}=\gamma_{0}+\gamma_{1} \varepsilon_{t-1}^{2}+\delta \sigma_{t-1}^{2},
\end{aligned}
$$


Table 1

Variable descriptions

\begin{tabular}{|c|c|c|c|}
\hline Variable & Mean $^{\mathrm{a}}$ & Description & Source \\
\hline 1. Investment Rate $(I / G D P)$ & $-1.06 \%$ & $\begin{array}{l}\text { Share of gross (total) fixed } \\
\text { investment of total GDP at } \\
\text { constant prices of } 1993 \text {. }\end{array}$ & INEGI, Mexico \\
\hline 2. GDP tradable goods & $2.50 \%$ & $\begin{array}{l}\text { GDP of manufactures, and } \\
\text { agriculture at constant prices of } \\
1993 \text {. }\end{array}$ & INEGI, Mexico \\
\hline 3. GDP non-tradable goods & $1.16 \%$ & $\begin{array}{l}\text { GDP of construction, electricity, } \\
\text { gas and water at constant prices of } \\
1993 \text {. }\end{array}$ & INEGI, Mexico \\
\hline $\begin{array}{l}\text { 4. Relative price of capital } \\
\text { goods }\end{array}$ & $2.64 \%$ & $\begin{array}{l}\text { Ratio of price index of capital } \\
\text { goods over the CPI }(1993=100) \text {. }\end{array}$ & $\begin{array}{l}\text { Own calculations based } \\
\text { on INEGI, Mexico }\end{array}$ \\
\hline 5. Real interest rates (RIR) & $-3.12 \%$ & $\left((1+i) \times(1-\pi)^{4}\right)-1$ & Own Calculations \\
\hline $\begin{array}{l}\text { 6. Domestic nominal interest } \\
\text { rates }(i)\end{array}$ & & $\begin{array}{l}\text { (Annualized quarterly) Money } \\
\text { market rate. Period average. }\end{array}$ & $\begin{array}{l}\text { International Financial } \\
\text { Statistics, IFS, IMF }\end{array}$ \\
\hline 7. Inflation $(\pi)$ & & $\begin{array}{l}\text { (quarter on quarter) Rate of } \\
\text { growth of quarterly CPI } \\
(1993=100) \text {. }\end{array}$ & $\begin{array}{l}\text { Own calculations based } \\
\text { on INEGI, Mexico }\end{array}$ \\
\hline 8. US real interest rate & $8.51 \%$ & $((1+\mathrm{US} i) \times(1-m))-1$ & Own Calculations \\
\hline $\begin{array}{l}\text { 9. US Nominal interest rates } \\
\text { (USi) }\end{array}$ & & $\begin{array}{l}\text { Prime bank lending rate } \\
\text { (annualized). }\end{array}$ & $\begin{array}{l}\text { International Financial } \\
\text { Statistics, IFS, IMF }\end{array}$ \\
\hline $\begin{array}{l}\text { 10. Rate of growth of the } \\
\text { import unit value index }(m)\end{array}$ & & $\begin{array}{l}\text { Rate of growth of the import unit } \\
\text { value index (average quarterly). }\end{array}$ & $\begin{array}{l}\text { International Financial } \\
\text { Statistics, IFS, IMF }\end{array}$ \\
\hline 11. Real exchange rate (RER) & $0.84 \%$ & Real effective exchange rate. & $\begin{array}{l}\text { International Financial } \\
\text { Statistics, IFS, IMF }\end{array}$ \\
\hline 12. Credit to the private sector & $1.00 \%$ & $\begin{array}{l}\text { Credit to private sector by deposit } \\
\text { money banks and other banking } \\
\text { institutions. }\end{array}$ & $\begin{array}{l}\text { International Financial } \\
\text { Statistics, IFS, IMF }\end{array}$ \\
\hline $\begin{array}{l}\text { 13. Volatility of the real } \\
\text { exchange rate }\end{array}$ & $2.48 \%$ & $\begin{array}{l}\text { Conditional Variance of the } \\
\text { Garch }(1,1) \text { AR(1) of the IFS } \\
\text { quarterly Real Exchange Rate. }\end{array}$ & Own Calculations \\
\hline $\begin{array}{l}\text { 14. US Gross domestic } \\
\text { product (USGDP) }\end{array}$ & $3.23 \%$ & $\begin{array}{l}\text { US GDP in billions of chained } \\
1996 \text { dollars }\end{array}$ & http://www.economagic.com \\
\hline 15. Terms of trade & $-3.50 \%$ & $\begin{array}{l}\text { Ratio of Mexico's export and } \\
\text { import price indexes }(1993=100)\end{array}$ & HAVER, Emergela \\
\hline 16. Dummy Crisis 1982 & & $\begin{array}{l}\text { Dummy variable designed to } \\
\text { capture the effect of financial } \\
\text { crisis in the Mexican economy. } \\
\text { The periods selected correspond to } \\
\text { the quarters for which there was a } \\
\text { negative rate of growth (y on y). } \\
\text { The 1982 crisis covers 1982: Q3 } \\
\text { to 1983: Q4; The } 1995 \text { crisis } \\
\text { covers 1995: Q1 to } 1995 \text { : Q4; The } \\
\text { last dummy covers both crises. }\end{array}$ & Own Calculations \\
\hline $\begin{array}{l}\text { 17. Dummy Crisis } 1995 \\
\text { 18. Dummy Crises } 1982 \text { and } \\
1995\end{array}$ & & & \\
\hline
\end{tabular}

\footnotetext{
a Mean of the rate of growth for all the variables included in regressions, except US and Mexican interest rates (nominal and real), which are in levels. Period: 1982: Q1-2000: Q2.
} 
where $\sigma^{2}$ denotes the variance of the error term $(\epsilon)$. The uncertainty measure is therefore the fitted value of $\sigma^{2}$ in (14).

Real interest rates are expected to have negative effects on investment. Yet it is commonplace to find no significant relationship between real interest rates and investment-output ratios in cross-country studies (Agosín, 1996; Servén, 1998), as well as in studies of Mexican investment (Warner, 1994). One possible explanation for this common finding is that it is difficult to ascertain which real interest rate is the one being used by domestic borrowers, and therefore the usual average rates reported by the Central Bank may not provide an accurate indicator of the real cost of borrowing. In the Mexican case, it is possible that large Mexican firms actually finance their investment activities by tapping US financial markets (Krueger and Tornell, 1999). For this reason, the basic empirical model is extended to consider both the average quarterly domestic rate and the US rate. That is, we test the hypothesis that credit markets in Mexico are segmented. As a proxy for the domestic nominal interest rate, we use the money market rate as reported by the IMF's International Financial Statistics. For the US rate, we use the prime lending rate from the same source. To derive the real interest rates, the money market rate was deflated by the inflation of consumer prices, and the US prime rate was deflated by the inflation of US import prices. The model is also extended to test for the presence of credit rationing, by including the credit to the private sector measured as the sum of the claims on the private sector held by commercial banks and other financial institutions.

In searching for "confidence" effects, we extend the basic model to include crisis dummy variables interacted with the domestic real interest rate. During the period under analysis, Mexico had two crises: the debt crisis (1982: Q3 to 1983: Q4) and the Tequila crisis (1995: Q1 to 1995: Q4). To identify confidence effects during these times, we introduce one dummy variable for both crises (as a mean-shifter) and a dummy variable for each crisis interacted with the domestic real interest rate. The crisis mean-shifter dummy variable is triggered during both periods, while the interacted dummies are specific to each crisis. The sign and significance of the interactive variables is a test of the stability of the coefficient on the real interest rate.

\section{Pre-testing, estimation strategy, and specification tests}

One of the first decisions taken was to choose between the estimation of the investment function as in eq. (12) or another specification depending on the presence of unit roots in the series. Traditional tests for unit roots are based on univariate tests developed by Dickey and Fuller (1981) and Phillips and Perron (1986). These tests assume that there is only one possible root with zero frequency. Many high frequency time series have seasonal components which can be either deterministic or stochastic. If the series only have deterministic seasonality then seasonal dummy variables will solve the problem. If the series also have stochastic seasonality, it is important to use other filters, such as the fourth-difference (or year-on-year difference) used to eliminate seasonality in Box-Jenkins methods. To clarify this distinction, consider a series with the following data generation process: 


$$
y_{t}=\gamma y_{t-4}+\varepsilon_{t}, \varepsilon_{t} \sim \operatorname{iid}\left(0, \sigma^{2}\right) .
$$

By substracting $y_{t-4}$ on both sides, (15) becomes:

$$
\Delta_{4} y_{t}=(\gamma-1) y_{t-4}+\varepsilon_{t} \text {. }
$$

Eq. (16) shows that if $\gamma=1$, shocks are permanent with seasonal periodicity. High frequency series with seasonal unit roots need to be differenced appropriately, in this case using fourth differences.

Hylleberg et al. (1990) developed a test for stochastic seasonal roots, which is explained in Appendix A. The HEGY unit root test results are presented in Table 2. Only a few variables do not have some form of unit roots. These are the domestic real interest rate, the US real interest rate, and RER volatility. All the other variables have unit roots of zero frequency (i.e., quarterly), and tradables and non-tradables also have other seasonal unit roots. Maddala and Kim (1998) argue in favor of using a uniform filter for series with unit roots, due to evidence of asymptotic biases in linear regressions models when series are filtered differently. There are no studies that address this issue in the context of GMM estimators, but to be safe, we use a single filter, the fourth difference, for the series in our model that had unit roots of any kind. Hence the results in Table 2 led us to estimate the following model instead of (12):

$$
\left(\frac{\hat{I}}{G D P}\right)=C+m_{T} \hat{Y}_{T}+m_{N T} \hat{Y}_{N T}+I\left(R I R, \hat{P}_{K}, \hat{\sigma}_{R E R}\right) .
$$

\begin{tabular}{|c|c|c|c|c|c|}
\hline Variable & $\begin{array}{l}\text { HEGY } \\
\text { Aux. } \\
\text { Regr. }^{\text {e }}\end{array}$ & $\begin{array}{l}\text { ' } t \text { ': } \pi 1 \\
\text { (quarterly) }\end{array}$ & $\begin{array}{l}\text { ' } t \text { ': } \pi 2 \\
\text { (biannual) }\end{array}$ & $\begin{array}{l}' F: \pi 3=\pi 4=0 \\
\text { (annual) }\end{array}$ & Comment \\
\hline 1. Investment/GDP & $\mathrm{C}, \mathrm{T}, \mathrm{SD}$ & 3.36 & $-2.89^{a}$ & $8.91^{\mathrm{c}}$ & \\
\hline 2. Tradables GDP & $\mathrm{C}, \mathrm{T}, \mathrm{SD}$ & -1.69 & -2.36 & 4.85 & \\
\hline 3. Non-tradables GDP & $\mathrm{C}, \mathrm{T}$ & -2.61 & $-2.24^{\mathrm{b}}$ & 2.05 & \\
\hline 4. Relative price of capital & $\mathrm{C}, \mathrm{SD}$ & -1.01 & $-6.83^{\mathrm{c}}$ & $16.15^{\mathrm{c}}$ & \\
\hline 5. Real Interest Rates ${ }^{\mathrm{d}}$ & $\mathrm{C}, \mathrm{T}, \mathrm{SD}$ & $-4.00^{\mathrm{a}}$ & $-5.25^{\mathrm{c}}$ & $39.29^{c}$ & Stationary \\
\hline 6. US Real Interest Rates ${ }^{d}$ & $\mathrm{C}, \mathrm{T}, \mathrm{SD}$ & $-4.04^{b}$ & $-6.41^{\mathrm{c}}$ & $18.77^{\mathrm{c}}$ & Stationary \\
\hline 7. Volatility of the RER & $\mathrm{C}$ & $-3.92^{\mathrm{c}}$ & $-6.79^{c}$ & $31.30^{\mathrm{c}}$ & Stationary \\
\hline 8. US GDP & $\mathrm{C}, \mathrm{T}, \mathrm{SD}$ & -3.00 & $-5.29^{c}$ & $54.57^{\mathrm{c}}$ & \\
\hline 9. Terms of Trade & $\mathrm{C}, \mathrm{SD}$ & -2.55 & $-4.03^{c}$ & $13.97^{\mathrm{c}}$ & \\
\hline $\begin{array}{l}\text { 10. Credit to Private } \\
\text { Sector }\end{array}$ & $\mathrm{C}, \mathrm{SD}$ & -1.43 & $-4.40^{c}$ & $55.40^{\mathrm{c}}$ & \\
\hline
\end{tabular}

Table 2

Tests for zero and seasonal unit roots in the (log of the) levels of Mexico's variables

\footnotetext{
a Reject the hypothesis of unit root at $10 \%$.

${ }^{b}$ Reject the hypothesis of unit root at $5 \%$.

${ }^{c}$ Reject the hypothesis of unit root at $1 \%$.

${ }^{\mathrm{d}}$ Not in logs.

${ }^{\text {e }}$ C: Constant, T: Trend, SD: Seasonal Dummies.
} 
The GMM estimator allows for the estimation of the coefficients in (17) using as instruments any exogenous and pre-determined variables, including lagged explanatory variables. Testing the validity of the moment conditions is crucial to ascertain the consistency of GMM estimates. If the regression specification "passes" the test, then we can interpret the statistical and economic significance of the estimated coefficients as effects going from the explanatory variables to investment, and we can safely discard the possibility that these effects are due to some omitted variable correlated with the instruments. The specification test we use is the test of overidentifying restrictions introduced in the context of GMM by Hansen (1982) and further explained in Newey and West (1987). Intuitively, the fact that we have more moment conditions (instruments) than parameters to be estimated means that the estimation could be done with fewer conditions. The GMM approach estimates the error term under a set of moment conditions that excludes one instrumental variable at a time, and then tests the validity of the null hypothesis that each error term is uncorrelated with the instrumental variable excluded from the corresponding instrument set. In other words, the null hypothesis of Hansen's test is that the overidentifying restrictions are valid and a high $p$-value supports the model specification.

In the empirical model, the growth of output is expected to have a multiplier effect on the growth of the share of investment in GDP. However, the tradable sector could have a larger effect, perhaps, due to differences in the capital intensity of production-see the model presented in Section $3 .^{7}$ To test this hypothesis we rely on Wald tests of the specification restriction that the sectoral multipliers are equal (i.e., $m_{T}=m_{N T}$ ). More specifically, the tables with regression results report the $p$-value of the $F$-statistic for the null hypothesis that the sectoral multipliers are equal. Therefore a low $p$-value (below 0.10) indicates that the multipliers are not equal.

Due to the possibility that we have omitted variables in the specification of the Mexican investment function, the presentation of the regression results includes the $p$-value of the $Q$-statistic for serial correlation. The $Q$-statistic is a test of the null hypothesis that the correlation among error terms is zero. Therefore a high $p$-value (greater than 0.10) supports the specification of the model. The tables with regression results present the $p$-value of the $Q$-statistic corresponding to the correlation between the current error and its counterparts lagged 1 and 4 quarters.

The instruments for endogenous variables are the lagged values of the explanatory variables themselves, plus a set of exogenous variables that includes the US real interest rate, the growth of US GDP, and variations in Mexico's terms of trade. A difficulty arises when choosing the number of lags of the endogenous variables that are used as instrumental variables. We considered sets of 1,4 and 8 lags for all instrumental variables in view of the seasonality of the quarterly time series. Regressions with instruments with 8 lags could not be run for all specifications of the model due to the limited number of observations relative to the number of instruments. With one lag, several specifications did not pass either Hansen's test for overidentification nor the $Q$-test for serial correlation. Consequently we were left

\footnotetext{
7 This paper does not directly test the hypothesis that factor intensity in the tradables sector is higher.
} 
with 4 lags of the endogenous variables to be used as their instruments. ${ }^{8}$ However, a specification with two lags for the instrumental variables is used for the out-ofsample forecast exercise, because the reduced sample covering the period between 1981 and the end of 1994 included only 50 observations and hence we reduced the number of instruments from 29 to 19 .

In sum, our initial investment function has as the dependent variable the growth of the (fixed) investment rate. The explanatory variables include the growth of the sectoral GDPs, the domestic real interest rate, RER volatility, variations in the relative price of capital, and the lagged dependent variable. This model is extended along four dimensions: We first test the stability of the coefficient on the domestic real interest rate during periods of crisis. In the third estimation we add the US real interest rate, and credit availability to the private sector. These functions are estimated for the whole sample (1981: Q1-2000: Q2). Finally, we estimate a model that controls for the effect of the 1982 crisis for a restricted sample (1981-1994). The aim of this last estimation is to conduct an out-of-sample forecast. For each model, we report three specification tests: Hansen's $J$-test for overidentifying conditions; the Wald test for equality of the sectoral multipliers; and the $Q$-test for serial correlation.

\section{Results}

\subsection{Basic model}

The $J$-test of the basic investment function (first column, last row in Table 3) shows that the instrumental variables are not correlated with the error term: the $p$ value of the null hypothesis that the instruments are not correlated with errors is 0.88. Therefore we can interpret the coefficients as being the impact from the explanatory variables on the dependent variable.

An important result is that the multiplier effect of the tradable sector on investment clearly surpasses that of the non-tradable sector. The coefficients for tradables and non-tradables have statistically different magnitudes, according to the low $p$-value of the Wald test. The coefficient for tradables implies that an increase of one percent in the growth rate of tradables leads to an increase of 0.85 percent in the growth of the investment rate. The same increase in non-tradables leads to an increase of 0.46 percent in the growth of the investment share. The volatility of the real exchange rate has a negative sign and is significant at the 5 percent level. This coefficient implies that an increase of one percent in the growth rate of the volatility "causes" a reduction of 0.01 percent in the growth of the investment share. The domestic real interest rate also has a negative coefficient significant at the 5 percent level. The estimated coefficient implies that a one percentage point increase in the real interest rate leads to a 0.06 percent decline in the growth of investment relative to GDP.

\footnotetext{
${ }^{8}$ Instrumental variables for $X(t)$ are $X(t-1), X(t-2), X(t-3)$, and $X(t-4)$.
} 
Table 3

GMM regression results: Investment function

Dependent VariableExplanatory Variables ${ }^{\mathrm{e}}$
(1)Growth Rate of (2)Growth Rate of (3)Growth Rate of (4)Growth Rate of Investment/GDP Investment/GDP Investment/GDP Investment/GDP

$\bar{c} \bar{c} \bar{c}$

\begin{tabular}{|c|c|c|c|c|}
\hline Constant & $-0.04^{\mathrm{b}}(0.01)$ & $-0.03^{\mathrm{b}}(0.01)$ & $-0.02^{\mathrm{b}}(0.01)$ & $-0.07^{\mathrm{b}}(0.01)$ \\
\hline Lagged Investment & $0.34^{\mathrm{b}}(0.03)$ & $0.35^{\mathrm{b}}(0.04)$ & $0.34^{\mathrm{b}}(0.03)$ & $0.26^{\mathrm{b}}(0.08)$ \\
\hline GDP non-tradables & $0.46^{\mathrm{b}}(0.07)$ & $0.30^{\mathrm{b}}(0.12)$ & $0.13(0.10)$ & $0.66^{\mathrm{b}}(0.21)$ \\
\hline GDP Tradables & $0.85^{\mathrm{b}}(0.08)$ & $0.96^{\mathrm{b}}(0.14)$ & $1.00^{\mathrm{b}}(0.17)$ & $0.88^{\mathrm{b}}(0.27)$ \\
\hline Volatility RER & $-0.01^{\mathrm{b}}(0.00)$ & $-0.02^{\mathrm{b}}(0.00)$ & $-0.03^{\mathrm{b}}(0.00)$ & $0.00(0.01)$ \\
\hline $\begin{array}{l}\text { Relative Price of } \\
\text { Capital }\end{array}$ & $-0.06(0.07)$ & $0.04(0.14)$ & $0.09(0.13)$ & $-0.43^{\mathrm{a}}(0.25)$ \\
\hline $\begin{array}{l}\text { Domestic Real } \\
\text { Interest Rate }\end{array}$ & $-0.06^{\mathrm{b}}(0.02)$ & $-0.06^{\mathrm{a}}(0.03)$ & $-0.09^{\mathrm{b}}(0.03)$ & $-0.12^{\mathrm{b}}(0.05)$ \\
\hline Dummy for Crises & & $-0.05^{\mathrm{b}}(0.02)$ & $-0.08^{\mathrm{b}}(0.02)$ & $0.04(0.05)$ \\
\hline Crisis $82 \times$ Domestic & & $0.13(0.09)$ & $0.13^{\mathrm{a}}(0.07)$ & $0.46^{\mathrm{b}}(0.15)$ \\
\hline Real Interest Rate & & & & \\
\hline Crisis $95 \times$ Domestic & & $-0.29^{\mathrm{b}}(0.14)$ & $-0.22^{\mathrm{b}}(0.10)$ & \\
\hline $\begin{array}{l}\text { Real Interest Rate } \\
\text { US Real Interest Rate }\end{array}$ & & & $-0.00(0.03)$ & \\
\hline $\begin{array}{l}\text { Credit to Private } \\
\text { Sector }\end{array}$ & & & $0.05^{\mathrm{b}}(0.01)$ & \\
\hline Observations & 70 & 70 & 70 & 50 \\
\hline Adjusted $R^{2}$ & 0.89 & 0.88 & 0.84 & 0.87 \\
\hline S.E. of Regression & 0.05 & 0.04 & 0.05 & 0.05 \\
\hline $\begin{array}{l}Q \text {-stat at Lag } 1, p \text { - } \\
\text { value } Q \text {-stat at } \operatorname{Lag} 4, \\
p \text {-value }\end{array}$ & 0.240 .63 & 0.640 .51 & 0.790 .34 & 0.320 .22 \\
\hline Wald test, $p$-value & 0.00 & 0.01 & 0.00 & 0.63 \\
\hline$J$-test, $p$-value & 0.88 & 0.91 & 0.90 & 0.45 \\
\hline
\end{tabular}

${ }^{a}$ Significant at $10 \%$.

${ }^{\mathrm{b}}$ Significant at $5 \%$.

${ }^{c}$ Exogenous variables: US Real Interest Rates, US GDP, Terms of Trade, 4 lags of endogenous variables and seasonal dummy variables.

${ }^{d}$ Same exogenous variables but only 2 lags of endogenous variables and seasonal dummy variables.

e All variables are included in year-on year differences of their logs, except for Mexican and US Real Interest Rates which are in levels.

The relative price of capital also has the expected negative coefficient but the magnitude of this effect is not significantly different from zero.

\subsection{Searching for “confidence” effects}

This section aims to determine whether there is evidence of "confidence" effects during times of crisis. A confidence effect would be present in times when increases 
in interest rates are associated with increases in the growth rate of investment. This phenomenon can theoretically arise when high interest rates signal that the monetary authorities are willing to defend the value of the currency, thus protecting the net worth of firms with liabilities denominated in foreign currency. As explained by Bernanke and Gertler (1989), if investment is limited by the wealth of firms, then a negative shock leads to a fall of investment. Krugman (1999) suggests that this effect may have aided the recovery of Mexico after 1995 and Korea after 1998. The estimation strategy is to include the combined crisis dummy variable as a meanshifter, and each interacted crisis dummy is introduced separately. This approach is superior to the inclusion of the interacted term alone, because it prevents capturing a shift in the mean growth rate of fixed investment to GDP ratio during crises that may not be due to a structural change in the interest-rate coefficient.

The second column of Table 3 shows that the significant results from the basic model are unchanged. The coefficient for the interacted 1982 crisis dummy shows a positive sign but it is not significant. The coefficient for the interacted 1995 crisis dummy shows a negative and significant sign. The main conclusion that can be derived from this evidence is that we cannot reject the presence of a structural break in the interest-rate coefficient during 1995. In this case, high interest rates had more negative impact on the growth of the investment rate than during normal times. ${ }^{9}$

\subsection{Credit rationing and market segmentation}

At this point, it remains to be explored whether the recovery of Mexican fixed investment growth was due to the financial linkages with the US, as argued by Krueger and Tornell (1999). Another hypothesis to address is the effect of credit availability on the rate of growth of the investment share. More specifically, we want to explore whether the hypothesis of credit rationing applies to the Mexican experience. Under credit rationing, investment could be driven by credit availability for any given level of real interest rates (Stiglitz and Weiss, 1981).

The relevant results are in the third column of Table 3 . This model passes the specification tests. The domestic interest rate retains its significant and negative sign even after controlling for credit availability and the US real interest rate. The coefficient for credit to the private sector is also significant and implies that an increase of one percent in the growth rate of private credit leads to an increase of 0.05 percent in the growth of the fixed investment share. These results provide evidence of rationing: for a given real interest rate, an increase in credit leads to an increase in the growth of the investment share.

The domestic real interest rate maintains its significance even after controlling for US real interest rates. Although the coefficient for the US real interest rate is negative, it is not significant. Thus, there is only weak evidence that access to the US

\footnotetext{
${ }^{9}$ We acknowledge that we cannot test for "confidence" effects with a duration of less than one quarter, given the frequency of the available data.
} 
financial market by Mexico's firms operating in the tradable sector was a feature of the growth of the investment rate.

Regarding the other explanatory variables, the multiplier from the tradable sector remains significantly higher than that of the non-tradable sector, and the volatility of the RER presents negative coefficients that are significantly different from zero. The relative price of capital, on the other hand, has a positive coefficient but is not significant. The coefficient for the interacted term of interest rates with the 1982 1983 dummy crisis becomes significant in this specification, thus strengthening the hypothesis that there was a "confidence" effect during this crisis. ${ }^{10}$

\subsection{Forecasting the Tequila crisis and its aftermath}

The aim of this section is to evaluate the stability of the basic model used to test "confidence" effects by looking at the results for the same regression estimated only for the 1981-1994 period. We were unable to test the complete model reported in the third column of Table 3 for this sample due to the reduced number of observations. The results are presented in the fourth column of Table 3. In this sample, the coefficient on the relative price of capital as well as the coefficient on the interacted 1982-1983 crisis dummy have the expected sign and are significantly different from zero. Real exchange rate volatility is not significant and neither is the meanshifter dummy for 1982-1983 crisis. All the other coefficients retain their expected signs. This specification passes the test for serial correlation and the $J$-test shows that the instrumental variables are not correlated with the error term. The Wald test shows that the coefficient for tradables is not statistically different from that of nontradables for this shorter time period. Hence the higher tradables multiplier was present mostly after 1994.

To provide a visual illustration of the capacity of this basic model to explain the behavior of Mexican investment during and after the 1995 crisis, Fig. 2 presents the forecasted and actual values for the year-on-year growth rate of Mexican fixed investment over GDP. The forecasts presented here use the dynamic approach to forecasting, which calculates multi-step forecasts starting from the first period in the forecast sample (first quarter of 1995). The dynamic forecasting method uses the coefficients found in regressions done with the sample (in our case 1981-1994), to forecast (all) out-of-sample values for the dependent variable. This method is less 'accurate' than the static approach, which calculates a sequence of one-step-ahead forecasts using actual, rather than forecasted values for the lagged values of fixed investment growth. Figure 2 shows that this naïve model quite successfully explains the behavior of Mexican fixed investment. The Theil inequality coefficient comparing the forecast with the actual observations is very low at 0.17 (a zero would indicate a perfect fit). More importantly, 97 percent of this inequality is due to the covariance

\footnotetext{
${ }^{10}$ However, we acknowledge that this break may be due to other factors that are not really "confidence" effects. For example, the banking system was nationalized during that time, and the change in the coefficient's sign during that crisis may be due to interest-rate controls.
} 


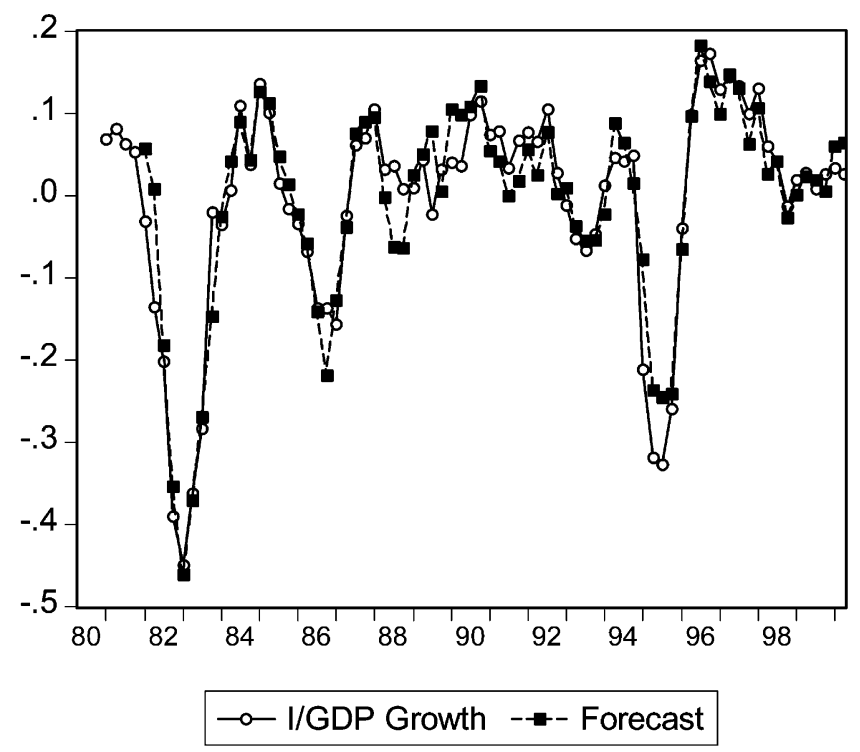

Fig. 2. Out-of-sample forecast of the recovery of Mexican investment growth, 1995-2000.

between forecast and actual errors (or deviations from the corresponding means). Hence the lion's share of the inequality between the forecasts and the actual observations is due to unsystematic error covariance.

\subsection{Contributions of explanatory variables to the growth of the investment share}

Table 4 shows the contributions of the growth rate of all the significant explanatory variables to the growth rate of investment to GDP ratio during 1995-2000. This exercise is based on the coefficients presented in the third column of Table 3, and the growth of the exogenous component of each explanatory variable. The exogenous component of each explanatory variable was derived from the fitted value of each explanatory variable after regressing each one of them on the entire set of instrumental variables used for the GMM regressions. Adjusted $R$ squares reported in Table 4 show that the instrumental variables are good predictors of the explanatory variables of the growth of the investment share. This strategy avoids the problem of endogeneity of the explanatory variables.

In 1995, the fixed investment to GDP ratio dropped by 28 percent. The contribution of tradables was -1.7 percent while the contribution of non-tradables was -2.0 percent. Note that even though the accelerator effect for tradables is bigger than for non-tradables, the contribution of tradables to the fall of the growth of the investment rate was smaller. The reason behind this smaller negative effect of tradables can be explained by the considerable increase of exports during this crisis (see Lederman et al., 2000). An important 6.3 percent of the fall was due to the effect 
of RER volatility, while other variables had minor effects. ${ }^{11}$ In 1996 , the fixed investment to GDP ratio increased by 9.9 percent, and 6.3 percent of this growth was due to the reduction in the volatility of the real exchange rate. About 7.3 percent was due to the contribution of tradables; 1 percent was due to the contribution of nontradables; and 2 percent to credit availability. For the period 1997-2000 the higher relative importance of the contribution of tradables is maintained. The contribution of real exchange rate volatility was around 1.3 percent (in absolute value), which is not negligible especially for the observed growth of investment to GDP ratio in the last couple of years (3 percent average between 1998-2000), and the contribution of credit availability and domestic interest rates were also important. In contrast, the contribution of variations in the US real interest rates seem to have been quite modest during the last five years. ${ }^{12}$

\section{Conclusions}

Since the eruption of the so-called Tequila crisis of 1995, and after the Asian crises of 1997, much has been written about the causes of financial crises in developing countries. Yet much less attention has been given to the evolution of the productive economy after crises. ${ }^{13}$ The stylized facts about the Mexican recovery show that fixed investment was crucial for the recovery. This study provided an empirical investigation of the determinants of the growth rate of fixed investment to GDP ratio in Mexico, with special attention given to the aftermath of the crisis of 1995. The only addition to basic models of investment in developing countries (which consider cost, scale and uncertainty factors) is the assumption that tradable and non-tradable output growth have different multiplier effects on investment growth. The main finding is that the basic model predicts fairly well the recovery of investment during 1996 and 1997. Results from investment functions estimated for the whole period indicate that the tradable sector had a higher multiplier effect on Mexican investment than the non-tradable sector. Domestic real interest rates and real exchange-rate volatility are also important determinants of the rate of growth of fixed investment. We found evidence of "confidence" effects only during 19821983. For the 1995 crisis, we find that increases in interest rates negatively affected investment, even to a higher degree than during normal times. Our evidence shows that credit availability had an independent effect on Mexican investment after controlling for real interest rates. This is consistent with the credit rationing hypothesis. Finally, there is only weak evidence that access to the US financial market by Mexico's firms was a key feature of the investment function during this period.

\footnotetext{
11 The sum of the contributions from all the variables reported does not equal the growth of fixed investment over GDP because there are other unobserved determinants of investment.

12 The table does not include contributions from the relative price of capital because this variable was statistically zero in this model.

13 See Perry and Lederman (1999) for a comparison of the aftermath of Latin American and Asian crises in the 1990 s.
} 
This work suggests some areas for further research. First, it is important to test the hypothesis that the tradable sector in Mexico is the leading sector due to a higher capital intensity of production. Another issue that needs closer analysis is the apparent irrelevance of the relative price of capital, controlling for RER volatility. We wonder whether this result will hold when using firm-level data. Credit market segmentation is another feature of the Mexican economy for which our results were rather unsatisfactory. Firm-level data would permit a more detailed and precise analysis of credit market imperfections by increasing the degrees of freedom, which are needed to study effects of different types of interest rates and other financial variables from Mexico and the United States.

\section{Acknowledgements}

We are grateful to Luis Servén, Eliana Cardoso, Alejandro Werner, Michael Melvin, and an anonymous referee for insightful comments on an earlier version of this paper.

\section{Appendix A}

\section{HEGY tests for seasonal roots}

The HEGY OLS regression estimated for each variable was:

$$
\Delta y=c+\alpha t+\pi_{1} z_{1}+\pi_{2} z_{2}+\pi_{3} z_{3}+\pi_{4} z_{4}+\beta \sum_{i=1}^{n} y_{t-i}+\mu_{t}+\varepsilon_{t} .
$$

The $c$ is a constant and $t$ stands for the time trend. The $\mu_{t}$ is a deterministic seasonal effect. It was an empirical question whether the data generation process for each variable includes these three elements. The inclusion of these elements affects the distribution of the $t$-statistics for the $\pi \mathrm{s}$, which are the parameters to be tested. The $z \mathrm{~s}$ in (18) are lagged polynomial representations of each variable $(y)$ in levels:

$$
\begin{aligned}
& z_{1}=y_{t-1}+y_{t-2}+y_{t-3}+y_{t-4} \\
& z_{2}=-y_{t-1}+y_{t-2}-y_{t-3}+y_{t-4} \\
& z_{3}=-y_{t-2}+y_{t-4}
\end{aligned}
$$

and

$$
z_{4}=-y_{t-1}+y_{t-3} \text {. }
$$

There are no seasonal unit roots if $\pi_{2}$ and either $\pi_{3}$ or $\pi_{4}$ are different from zero. For a series to be stationary (i.e., without any unit root), each $\pi$ must be different from zero. A series has no annual unit root if the $F$-statistic for the null that $\pi_{3}=$ 
$\pi_{4}=0$ is statistically significant. Hylleberg et al. (1990) provide the critical values for the $t$-statistics corresponding to the estimated $\pi \mathrm{s}$ and for the aforementioned $F$ statistic. The critical values depend on whether the estimated models include the intercept and/or the deterministic time trend and/or seasonal dummies.

\section{References}

Agosín, M., 1996. Relación de dos regiones: La inversión en la América Latina y en el Asia Oriental. El Trimestre Económico 63, 1139-1169.

Bernanke, B., Gertler, M., 1989. Agency costs, net worth, and economic fluctuations. American Economic Review 79, 14-31.

Dickey, D.A., Fuller, W., 1981. Likelihood ratio statistics for autorregresive time series with a unit root. Econometrica 49, 1057-1072.

Hansen, L.P., 1982. Large sample properties of generalized method of moments estimators. Econometrica 50, 1029-1054.

Hylleberg, S., Engle, R.F., Granger, C.W.J., Yoo, B.S., 1990. Seasonal integration and cointegration. Journal of Econometrics 44, 215-238.

International Monetary Fund, 1996. World Economic Outlook. Washington, DC.

Krueger, A., Tornell, A., 1999. The role of bank restructuring in recovering from crisis: Mexico 199598. NBER Working Paper No. 7042.

Krugman, P., 1999. Analytical afterthoughts on the Asian crisis. Mimeo, http://web.mit.edu/krugman/www/minicris.htm

Lederman, D., Menéndez, A. M., Perry, G., Stiglitz, J., 2000. Mexico: Five years after the crisis. Annual Bank Conference on Development Economics. The World Bank, Washington, DC.

Maddala, G.S., Kim, I.M., 1998. Unit Roots, Cointegration, and Structural Change. Cambridge University Press, Cambridge, UK.

Maloney, W., Azevedo, R., 1995. Trade reform, uncertainty and export promotion: Mexico $1982-88$. Journal of Development Economics 48, 67-89.

Newey, W., West, K., 1987. Hypothesis testing with efficient method of moment estimation. International Economic Review 28, 777-787.

Perry, G., Lederman, D., 1999. Adjustments after Speculative Attacks in Latin America and Asia: A Tale of Two Regions? The World Bank, Washington, DC.

Phillips, P.D.B., Perron, P., 1986. Testing for a unit root in time series regression. Universite de Montreal. Centre de Recherche et Developpement en Economique 2186, Cahier, Canada.

Pindyck, R., 1988. Irreversible investment, capacity choice and the value of the firm. American Economic Review 78, 969-985.

Rama, M., 1993. Empirical investment equations for developing countries. In: Servén, L., Solimano, A. (Eds.), Striving for Growth after Adjustment: The Role of Capital Formation. The World Bank, Washington, DC.

Servén, L., 1998. Macroeconomic uncertainty and private investment in LDCs: An empirical investigation. World Bank Policy Research Working Paper No.2035.

Servén, L., 1999. Terms-of-trade shocks and optimal investment: another look at the Laursen-Metzler effect. Journal of International Money and Finance 18, 337-365.

Stiglitz, J.E., Weiss, A., 1981. Credit rationing in markets with imperfect information. American Economic Review 71, 393-410.

Warner, A.M., 1994. Mexico's investment collapse: Debt or oil? Journal of International Money and Finance 13, 239-256. 